\title{
Influence of Cross-Cultural Management on the Development of Tourism: Example of Požega-Slavonia COUNTY
}

\begin{abstract}
:
This paper analyses the influence of crosscultural management on the development of tourism, with the emphasis on Požega-Slavonia County. Management is an integral part of modern business and governance of resources. However, global market requires distinctiveness, something that differentiates a product or service from the competition. That is why cross-cultural management is gaining significance in modern business, since it is putting culture and tradition in the function of business and realising its potential primarily in tourism. By acknowledging cultural differences, cross-cultural management adapts those same differences to the needs of
\end{abstract}

business. Here it is important to know how to present and direct the richness of culture and tradition and make it sustainable. The example of Požega-Slavonia County (which is at the very bottom in Croatia in terms of development] points to the insufficient utilisation of possibilities that the cross-cultural management offers. The causes of this underdevelopment, despite a rich culture and tradition of Požega-Slavonia County, are truly numerous. But, with a well-thought-out strategy of cross-cultural management, the tourism in Požega-Slavonia County should become the key aspect in recognising this area as a place of oenogastro experience.

\section{Keywords:}

cross-cultural management, culture, tradition, tourism

\section{Author s data:}

${ }^{1}$ Mihaela Markovac, prof., Zdenko Turković Elementary School, Republike Hrvatske 26, Kutjevo, mihaela.markovac@gmail.com. 


\section{Introduction}

Management is a core component of modern business and governance. It helps to make people work together in achieving common objectives and developing common values. Good management enables participation in the market competition for all interested parties, i.e. to those who want to improve their business and to stand out in the market, thus distinguishing themselves from the competition. It can be rightly said that in the modern world there is no success in the reaching the potential or achieving objectives without management. If management is applied according to the principle of cultural differences, we arrive to the notion of cross-cultural management. By acknowledging cultural differences, crosscultural management adapts those same differences to the needs of business.

Cultural differences are mostly influenced by the culture and tradition of a population or a region within a country. Due to its historic heritage, croatia is especially characterised by richness of cultural diversities, which can be presented in different ways through culture and tradition. If adapted to modern needs, culture and tradition can be shaped through management and serve in the interest of business, for example in tourism. But, simply having a rich culture and tradition is not enough; it is necessary to know how to present them and apply them to the modern life style. A good example of that is Požega-Slavonia County which, despite a rich culture and tradition that are reflected in its own multiculturalism, does not achieve good tourist results. On the contrary, in terms of tourist visits, this county is at the very bottom compared with other Croatian counties and represents just $0.1 \%$ of total tourist visits at the state level.

This paper deals with cross-cultural management through the segment of culture and tradition. The emphasis is on the possibilities that this type of management has in tourism. The paper analyses the possibilities of usage of culture and tradition in Požega-Slavonia County. By considering the aforementioned statistical data on tourist visits in this county, the starting thesis refers to the insufficient quality of management of resources in Požega-Slavonia County. Therefore, we can ask the question why is tourist attendance in this county almost negligible? It is expected that the management of this county has certain shortcomings, primarily in determining common long-term objectives. The research methodology in this paper encompasses the analysis of available literature, secondary sources and open source documents.

\section{Cross-cultural approach to management: previous research}

Management and knowledge are closely connected, or even mutually conditioned, because management and knowledge have the social function and make the world and life more efficient only when they interact with each other. The opinion that management refers only and exclusively to economic processes is a fallacy. on the contrary, more or less every individual or an organisation, association and company meets some type of management in its business operations. An action plan or the organisation of a certain business process often has a key role in achieving a set objective. Also, it is wrong to think 
that a business objective refers only to profit, because both the profit and non-profit organisations must apply management rules in their activities if they want to be successful.

How can we then define management? Simply put: "Management is a scientific discipline which is researching the most rational ways of governing a company or state institution, or the practice and process of governing a company, organisation etc." [1] This indicates that management can be studied as a scientific discipline, but that it also has its social function, one that is primarily reflected in practice. Peter Drucker emphasises that social function when he says that management is a liberal skill: "Liberal because it deals with basics of knowledge, self-knowledge, wisdom and leadership; skill because it also deals with practice and application." [6] But, management strongly affects people, their lifestyle, values and development of community through its social function, so we can conclude that management has spread over a broad social structure.

But, to unequivocally define management is neither simple nor easy. What are the causes of difficulties of defining management? Vinko Belak points that: "Management is not a static term. It is comprised of activities of a manager and the employees, who are oriented towards completing the objectives of an organisation, which they must achieve by working together in changeable environments and conditions of strong competition." [2] Pere sikavica and Fikreta Bahtijarevič-šiber are dealing with semantical issues in defining management, because different terms related to management are given the same content and vice versa. According to them: "The term management, from case to case, is used in different meanings, firstly as governance, secondly as leadership (in most cases], and thirdly as organisation." [10] They point out that semantical problem of defining management is reflected in the absence of an adequate translation of the term management into croatian language. In Croatian language it mostly refers to governance.

Management does not affect only the sphere of private entrepreneurship, but it should also have a key role in an economic situation of a country, which would also imply a political will to improve it. Finding the most adequate way of steering the knowledge towards realisation of a certain objective should be a part of initial preparation and design of the strategy for economic development. Therefore, we come to the term cross-cultural management, which combines management and political will, with the emphasis on cultural differences which very much influence the business success in a country. Cross-cultural management implies a special kind of management, one which applies comparative research of different cultures and their influence on management and business model and business communication with the aim of business development. This approach is necessary in a process of globalisation where emphasising the differences or specificities can help the establishment on the product and service market. It is precisely because of the globalisation and the development of information and communication technology that the competition is stronger than ever before. That is the reason why understanding the cultural differences leads to realisation of a business or political objective. 
The founder of cross-cultural management is Geert Hofstede [13] who used a sample of fifty countries to develop a method which can be used to compare values and behaviours of certain populations, thus helping to avoid cultural shocks when doing business anywhere in the world. For evaluation of cultural values of a certain state, Hofstede lists the following factors: power distance index, i.e. what is an individual's attitude towards authority and power and how strong is a person's individualism relative to collective; uncertainty avoidance index, i.e. how much are people ready to accept new thoughts and ideas; relationship between sexes (masculinity and femininity); short-term orientations versus long-term orientations la country's strategic development plan); and indulgence versus restraint, i.e. population's tendency to hedonism. By accepting cultural differences, business communication also becomes cross-cultural, taking ambiguities and unpleasantness in a code of business conduct in a country to a minimum. It appears that the world is a global village only conditionally speaking, because each nation develops its sense of selfrespect and dignity and strengthens its national consciousness through the preservation of its cultural specificities. Cross-cultural approach to business is necessary in: international negotiations, international management and marketing, political activities and surely in tourism.

Culture and tradition in crosscultural management

Culture and tradition encompass a set of values, material and non-material heritage which differentiate one nation from another through their specificities. If well designed and managed in terms of marketing, and adapted to the needs of a modern man, culture and tradition can become an important factor in a nation's tourist offer. It is especially the cultural differences, which are partly a reflection of tradition, that enter the sphere of cross-cultural management.

Culture and tradition are inseparable parts of heritage. Ivan Cifric defines heritage in the following way: "Heritage is understood as naturally created and man-made material [settlements, buildings, tools) and non-material goods (customs, skills, knowledges) in which social cinheritance, relations in community and marriage, institutions] and spiritual heritage (values, moral, norms) can be differentiated as collective acquis. Heritage belongs to us and we to it. It is a relationship towards past, present and future, and it includes our right to use, obligation to preserve and duty to create for future generations." [4] Although the mentioning of heritage mostly makes us think about positive cultural acquis, heritage can also be negative, such as bad norms of conduct. But, the important thing with heritage is surely the connection between heritage and tradition. Tradition preserves cultural heritage, but it also changes it to a certain extent. We can say that heritage is renewable because with each new social structure, the relationship towards heritage also changes. According to Cifric: "Tradition reinforces and preserves cultural heritage, especially the nonmaterial culture, but it also operates selectively through time, so that some products of culture fall into oblivion." [4] Through its actuality, heritage regains its importance as a witness of time and strengthens national recognisability. 
Well-thought-out and marketed heritage is most commonly recognised through tourist offer or branding of a place, region or state. Recognisable cultural heritage often offers an advantage compared to competition. Vesna Vrtiprah states that: "Desire to discover an authentic heritage is almost always on the list of travel motives. Cultural and ecological content in tourist offers is gaining more and more significance in the modern world, and regional differences are becoming ever more important." [12] This is caused by the desire for an authentic experience, which a tourist can only enjoy in a natural environment and in interaction with an authentic cultural heritage. Vrtiprah emphasises that emotions are very important in selection of tourist destination. "Cultural resources must be a source of emotions for tourists, they must give them a specific experience, enable them to feel the history of a landmark and to enjoy their visit." [12] When choosing their holiday destinations, tourists are increasingly deciding for active vacations which combine different contents that largely include cultural heritage of a certain destination.

Culture and tradition usually invoke the spirit of the past, but, a well-thought-out marketing for heritage makes it contemporary, thus putting it ahead of competition. The imperative of tourist offer is no longer only to be the first, but also to be unique. Daniela Angelina Jelinčić says about that: "Tourism as a modern phenomenon appears to be in contradiction with heritage as an expression of history and tradition of a nation and locality. Depicting past in present, however, can create the perfect foundation for creation of cultural-tourist products, completed with contemporary world trends which are if favour of cultural tourism." [8]
It is precisely tourism that, according to Jelinčic, influences the maintenance and preservation of cultural heritage. "Forgotten knowledges about one's roots and pride of one's heritage can often thank the tourism for their renewed usage and preservation. That way, tourism gets an extremely important role in preservation of heritage." [8] However, even though there are multiple positive sides for local population, such as: expected increase in income and improvement in standard of living, feeling of pride of cultural heritage, strengthening of the identity, the negative sides of tourism should also not be forgotten. Those are: frustration of local population due to the fact that their daily lives are subordinated to tourism (for example in Venice and Dubrovnik) and creation of distorted values, such as high prices which are also affecting local population. We can ask the question how much does a place's subordination to tourism affect its cultural heritage? Jelinčić is of the opinion that it is important to keep in mind sustainable development of tourism. What does that term entail? "Sustainable development of cultural tourism should not involve what a tourist might want to see, but what the local community wants to show about itself." [8]

Therefore, it is indisputable that cultural heritage influences tourism and that tourism influences cultural heritage. But what about the authenticity of tourist offer? There is an impression that the authenticity is often pretended and that tradition is invented for the purpose of tourism. This is precisely where Jelinčić sees the adaptation to the needs of modern tourists. "In tourism, remains of the past serve only as raw material that should be mined and used in accordance with contemporary attitudes. Time is changing, as well as attitudes 
and values. For a modern tourist, an accuracy of presentation is often not important, and precisely due to the changes that the time brings, the presentation sometimes seems uninteresting. Therefore, it is about the ability of interpretation adapted to modern times." [8]

\section{Perspective of cross-cultural} management in tourism: the example of Požega-Slavonia County

Earlier it was mentioned that cross-cultural management is an integral part of management of tourism precisely because it is with a good marketing strategy with an emphasis on cultural differences that it is possible to be distinctive compared to competition. However, when setting up the strategy for tourism development, besides researching the existing conditions, supply and demand and conditions on the tourist market, it is also necessary to take into consideration the everyday political events, which are sometimes crucial in choosing tourist destination. For example, Egypt and Tunis are less and less attractive tourist destinations because of complicated political situations in those countries, while Turkey, which until recently was a tourist giant, is surely suffering decrease in revenue due to the terrorist attacks. of course, when designing a strategy for development of tourism of a country or a region, the involvement of government is necessary for the purpose of achieving the set tourist objectives and, in the end, generating the revenue.

Speaking about the perspective of development of Croatian tourism, the key document for insight into the existing conditions in Croatian tourism and its future development is a document released by the Government of Republic of Croatia entitled Tourism Development Strategy of the Republic of Croatia until 2020. [11] According to this document, tourism in Croatia is made up of natural resources and rich cultural and historic heritage. However, the most important problem is immediately noticed, and that is the insufficient utilisation of these same resources: "Despite an extraordinary wealth and abundance of those natural, historic and cultural attractions, only a small number of them is included in the overall offer." [11] This problem is complex and includes numerous factors such as: lack of tourist attractions and basing the offer on the most common tourist contents, which are the sea and the Sun $185 \%$ of Croatian tourist offer); poor transport infrastructure (primarily rail transport); lack of content and opportunities for sport and recreation; inadequate price and supply ratio; poor management marketing and direction of tourist offer; lack of web marketing; poor and complicated legal frameworks that are hindering the development of tourism; disparity in the representation of coastal and continental tourism [89:11\%]. [11] From that it follows that the most important features of Croatian tourism are: "Insufficient differentiation of products and services; lack of innovative and high quality guest accommodation; growth based primarily on the expansion of family accommodation in households, lack of quality hotel offers with an insufficient investment activity, insufficient connectivity via air or sea; static system of national marketing; low number of globally branded destinations; inadequate destination tourist infrastructure; and innerited orientation of the local population towards seasonal business." 
[11] In order to eliminate or at least reduce these deficiencies, the strategy sets out the strategic objectives and tasks of Croatian tourism to be achieved by 2020. These are: improvement of the infrastructure and quality of accommodation; new jobs; tourism investments amounting to EUR 7 billion and increase in spending to EUR 14.3 billion. Tourism Development strategy of the Republic of Croatia until 2020 is the core document detailing development of tourism in our country, and every strategy for tourism development at a local level is in line with it, including the strategy for tourism development in Požega-Slavonia County.

Evaluation of existing conditions in tourist offer in Požega-Slavonia County

According to the data provided by the Ministry of Tourism, the number of tourists visiting PožegaSlavonia County is stagnating, and is not showing signs of recovery or improvement. As can be seen in the following table, the share of the number of tourist arrivals in Požega-Slavonia County compared to the total number of tourist arrivals in the Republic of Croatia is only $0.1 \%$, and the development of Požega-Slavonia County tourism is at the very bottom compared to the other counties.

\begin{tabular}{lcc} 
Year & $\begin{array}{l}\text { Number of tourists } \\
\text { (in 000) }\end{array}$ & $\begin{array}{l}\text { Structure in } \\
\%\end{array}$ \\
\hline 2011. & 10 & $0.1 \%$ \\
2012. & 9 & $0.1 \%$ \\
2013. & 10 & $0.1 \%$ \\
2014. & 10 & $0.1 \%$ \\
2015. & 10.30 & $0.1 \%$ \\
\hline Table 1. Source: The Ministry of Tourism of the \\
Republic of Croatia [14]
\end{tabular}

For comparison, we can examine the number of tourists in all of the counties in eastern Slavonia. But, as we can see from the following table, PožegaSlavonia County is significantly lagging behind the other Slavonian counties as well.

\begin{tabular}{lcc} 
County & 2013 & 2014 \\
\hline Osijek-Baranja & 64.294 & 64.539 \\
Vukovar-Srijem & 46.039 & 50.690 \\
Brod-Posavina & 18.325 & 17.802 \\
Požega-Slavonia & & \\
$\begin{array}{l}\text { County } \\
\text { Virovitica- }\end{array}$ & 10.326 & 11.032 \\
Podravina & 7.965 & 8.992 \\
\hline
\end{tabular}

Table 2. Source: Tourist Board of the PožegaSlavonia County [16]

It follows that the tourist situation in PožegaSlavonia County is extremely negative despite its wealth of natural resources and cultural heritage. The causes of such poor statistics are: destroved tourist infrastructure cpartly during the Homeland War); traffic isolation of Požega-Slavonia County and poor traffic infrastructure; mined areas in the western part of the county; unorganised tourist offer; lack of marketing and promotional activities; lack of accommodation capacity; private accommodation makes up 98.50\% of total accommodation capacity; and poor educational structure of the population.

Factors of tourism development in PožegaSlavonia County

In accordance with Tourism Development Strategy of the Republic of Croatia until 2020, PožegaSlavonia County published its development strategy entitled County Development strategy of Požega-Slavonia County 2016-2020. [18] The document emphasises the factors of tourism development in the specified period; however, it 
should be noted that these are generally presented, without concrete measures for their enforceability.

According to the document, we can highlight the following factors of tourism development in the Požega-Slavonia County: cyclotourism, given there are $300 \mathrm{~km}$ of mountain bike trails in the county; camping tourism; protected areas such as the Nature Park Papuk; richness of forests and waters; rural areas; and cultural and historical material and non-material heritage. Emerging from this is the development of: hunting, cultural, archaeological, exploratory, research, health, recreational, rural, ecological and wine tourism. However, the emphasis in this County Development Strategy is placed on the development of rural tourism. "The significance of rural tourism is reflected in the interaction between agricultural production of traditional products, presentation of tradition (customs and heritage), traditional gastronomy and other tourist services. The development of rural tourism is based on sustainable development, and is reflected in revitalisation of traditional heritage that is given a new, tourist purpose, which has a valorising, presentational and educational role." [18]

However, even though there is a cross-cultural approach to addressing the problem of the tourist offer of the Požega-Slavonia County, given there is an emphasis on the valorisation of cultural heritage or cultural differences, there is no description of the concrete measures to achieve set objectives, which represent half of the way to success. According to Drucker: "The mission of an organisation must be clear enough and large enough to create a common vision. General objectives that make that vision must be clear, public and constantly reaffirmed. The first goal of the management is to thoroughly consider, set and interpret those specific objectives, values and general objectives of the organisation that it leads." [6] Therefore, the result of a good management is the achievement which is used to measure the achieved objective, which can only be reached by well-directed management.

Drucker also answers the question about the importance of cross-cultural approach to business. According to him, management integrates people into a joint endeavour, thus becoming an integral part of the culture. Managers are performing the same job in different parts of the world, but the way they do it can and must be different, depending on the cultural differences. According to Drucker: "One of the main challenges that managers in developing countries face is to find and identify those elements of their tradition, history and culture that can be used for the design of management." [6] We can apply those principles of cross-cultural management to the strategy for tourism development in PožegaSlavonia County. If the management of PožegaSlavonia County applies the methods of successful tourist management of, for example, Istria or northern Adriatic and infiltrates it in its cultural ground, we can expect results and success in business and governance.

Strategy for tourism development in PožegaSlavonia county with an emphasis on crosscultural approach

Požega-Slavonia County is located in the continental part of Republic of Croatia and is dominated by lowland and mountain relief. In administrative terms, the county is divided into five towns: Požega, Pakrac, Lipik, Pleternica and Kutjevo, and five municipalities that that occupy the rural part of the county: Brestovac, Čaglin, Jakšić, Kaptol and Velika. Forests cover $45.26 \%$, and arable land $41.93 \%$ of the county. There are 142223 ha of arable land planted with grape vine. 
[18] This statistical data points to the great opportunities that Požega-Slavonia County has in developing rural tourism, with an emphasis on oenotourism and gastro tourism. The first step in that process would be to use natural and cultural resources, and to brand Požega-Slavonia County as a place of quality oenological and gastro offers, with an authentic experience of rural and traditional tourism. Here, food and wine should have the central role. Supporting this idea is the study by Berislav Bolfek and others about the perception of Slavonia as a region, and the fact that $29 \%$ of the subjects think about Slavonia as a region of wine and tasty traditional food. [3]

Požega-Slavonia County should strengthen and develop its reputation as a destination of highquality wine and traditional food. The aim of such branding is to discover and highlight the specifics of an offer compared to competition, to become recognisable and, finally, to attract a higher number of tourists, influence the image of a destination, and, consequently, achieve greater revenue. Since there is an ever-growing trend of returning to nature and authentic experience of tradition, tourist offer can be shaped through rural tourism. But, as Damir Demonja and Robert Baćarac claim: "Rural tourism was not formed simply as a need for new tourist capacities laccommodation units, catering establishments restaurants and other commercial tourist facilities], but also as a need to preserve, revitalise and give a new added value to heritage and authentic promotion of traditional knowledge and skills through the organisation of attractive and original tourist offer." [5] This includes various forms of tradition and cultural heritage: buildings, gardens, folk customs, ways of dressing, songs, dances, food, drinks etc, or, in other words, everything that is a reflection of cultural heritage, and thus forms the spirit of time and space in an authentic way. Besides the already mentioned gastronomy and oenology, also contributing to the thesis about the development of rural tourism is a rich multicultural and ethnological heritage in this area, supported by the fact that $9.6 \%$ out of county's total population of 78.034 are members of national minorities [Serbs, Czechs, Italians, Albanians, Hungarians, Slovaks]. [18] We should not forget that characteristics of cross-cultural management are well-managed cultural differences.

But, why should gastronomy and oenology be the main brand carriers of Požega-Slavonia County? Simply put, gastronomy and oenology in this part of Croatia are especially rich and already widely recognisable, and as such should be shaped through marketing and management as parts of cultural heritage, since attractiveness of a destination can only be achieved through originality and authenticity. According to the recommendation in Tourism Development Strategy of the Republic of Croatia until 2020, the target groups of oenotourism and gastro tourism are: DINKS lcouples with two incomes and without children], empty nesters [couples with independent children], golden age above 65 years and specialised travel agents. Therefore, tourist offer of the county should be adapted to these target groups. In the process of branding the Požega-Slavonia county as an oenotourism and gastro destination, it is necessary to use more of information and communication technology, enrich the gastro offer, develop educational programmes, open and organise wine roads, and connect local food producers with the catering sector.

Gastronomy can thus be the main driver of travel, or it can be a deciding factor when choosing a holiday destination. Some destinations, such as Tuscany, have built their image precisely on 
gastronomy. It is important to emphasize that gastronomy can help with the lack of other content in tourist offer and affect the overall experience of the destination. Ana Žaper says about that: "Cookery is obviously a part of the identity and contributes to the tourist image. Some destinations have a decidedly gourmet image and visitors come there to enjoy the well-known specialties." [17] that way gastronomy becomes a part of cultural heritage. According to Ľaper: "Cuisine is associated with the culture of the people and the environment, so the search for original elements has a great significance for preserving the heritage." [17] We can agree with this statement because food tastes and aromas, and the way of its preparation or presentation also constitutes the cultural heritage of a nation. But we can also wonder why gastronomy is not more significantly represented in the branding of some destinations, namely Slavonia or Požega-Slavonia County? The answer lies in the fact that even the local population is often not sufficiently aware of its own spiritual and cultural values, and it is also due to the poor mutual cooperation between local authorities and the cultural and tourist sector, administration, financing problems and inadequate education of the population. We can recognize similar problems in Požega-Slavonia County. Still, the following project shows a good example of how to make gastronomy recognisable through a joint project of cross-cultural management. It is the project headed by city museum of Požega called Museum in a Pot. The project was initiated with the objective of rediscovering forgotten cuisine, and reconstructing and documenting the gastronomicgourmet tradition of Požega and surrounding area. Through educational workshops, exhibits, and cooperation with the local community, restaurants and the local population, the gourmet tradition of
Požega-Slavonia County has thus been revitalised and brought back to the light of day. [15]

Recognisable gastronomy is associated with wine tourism or oenotourism. Since Požega-Slavonia County is known for its high-quality wines and has a long wine-making tradition which has become a part of the cultural heritage of this area, there are major prerequisites for branding Požega-Slavonia County as the centre of oenotourism in Slavonia. Supporting that claim is the fact that Kutjevo, one of the most prominent wine growing regions in Croatia, is located in the eastern part of PožegaSlavonia County and produces $27 \%$ of total amount of graševina (welschriesling) produced in Croatia. Oliver Kesar and Danijela Ferjanić define oenotourism as: "A specific form of tourism which does not include just wine tastings in places outside of permanent residence, but it also includes various activities such as visits to vinevards and wineries, participations in wine festivals and visits to wine exhibits, educational and cultural aspects of production and consummation of wine, and many other winerelated activities in open and closed spaces." [9] Therefore, the first prerequisite for branding the Požega-Slavonia County as an area of oenotourism must surely be a good management of that process. But how is success of oenotourism reflected? According to Kesar and Ferjanic: "Oenotourism can be successfully developed in regions that have preserved natural values, a long wine-making tradition and appropriate technology, even in times of economic crises, but it requires timely reaction, careful planning and sophisticated advertising." [9] of course, the latter refers to the timely management which includes management of the existing resources in order to achieve the objective, which is to brand the county as recognisable oenologist region. That would primarily refer to creation and development 
of wine roads in the eastern part of the county, where visitors can experience the unique features of this wine region, the cultural identity and tradition related to oenology and gastronomy, and thus the social dimension of this region. A good step in the management during the branding process could be the creation of clusters of manufacturers from the area, primarily food and wine manufacturers. According to Kesar and Ferjanić, creation of clusters has multiple significance in the development of tourism and economy. They explain that: "Such clusters represent the key component of rural tourism development, where the creation of the network for development of oenotourism equally implies horizontal (within the wine industry) and vertical integration between several branches of industry], thus creating a complex cross-sectoral network with a clear vision, mission and goals." [9] Clusters in the area of Požega-Slavonia County would create better business opportunities for small manufacturers and would allow them the inclusion in a market race where they can hardly succeed themselves.

Negative sides of oenotourism should also be mentioned. First of all, there is an inadequate awareness of wine producers about business practices and market rules. That means that most wine producers are concentrated only on the winemaking process, while they completely neglect marketing, not realising that the time when wine was sold exclusively in cellars has passed. The image of oenotourism should also be influenced. As Kesar and Ferjanić say: "Although wine roads, wineries, and especially wine cellars can develop an exclusively designed tourist product, the image of oenotourism is still linked to village and rural mentality and as such has limited opportunities to become a product with a high added value." [9] Therefore, the trend of a multidimensional experience of the wine region should become an imperative, and the idea of wine as a way of living should be promoted. The problems that arise in the development of oenotourism are local authorities' lack of interest in development projects, the lack of a common goal and vision for development of the region, the lack of investment, and the resistance of the local population to change. Supporting the last claim is the index of (under)development of Požega-Slavonia County despite numerous natural and cultural resources, which are not purposefully or reasonably managed with regard to developmental. According to the data by Ministry of Regional Development and EU Funds for 2013, the development index for Požega-Slavonia County is $33.81 \%$, or $75 \%$ less than the state average, with the average unemployment rate of $64.66 \%$, placing this county among the five most underdeveloped counties in Croatia. [7]

Since good management is the basis of every successful business, that should also apply to the example of regional development, in this case the Požega-Slavonia County. But, according to Drucker, only the question: "What will be our job?" has a goal of predicting changes. [6] Here it is not just about future business, but also about the systematic analysis of existing conditions and abandoning the outdated way of thinking and doing business, which is no longer bringing changes. According to Drucker: "Defining the purpose and mission is an arduous, painful and risky process. Objectives are not destiny; they direct. They are not commands; they are common commitment, an agreement. They do not determine the future; they are ways to mobilise the energy and resources of companies to create the future." [6] Crosscultural management can have a key role in that. 


\section{Conclusion}

This paper deals with cross-cultural management, with the emphasis on possibilities of this kind of management in Požega-Slavonia County. In modern business and governance, cross-cultural management is becoming ever more influential. By recognising and properly managing cultural differences, it is possible to improve the business or to achieve the objectives. Important segments of cross-cultural management are culture and tradition. When properly managed, they offer an advantage compared to competition, because culture and tradition guarantee cultural differences and authenticity, which are values that are very much in demand in the modern globalised world.

The example of Požega-Slavonia County demonstrates the lack of good cross-cultural management, because despite the wealth of natural resources, due to the lack of good management, the underdevelopment of this area is more than $75 \%$ of the state average. There are multiple reasons for this, and we can certainly find them in a poor management of culture and tradition of this area. Therefore, the emphasis in this paper is on better and more purposeful management of culture and tradition which can help the development of the county through rural tourism. Gastronomy and oenology should certainly have the kev role, since those are the elements that already have good predispositions for further development. But, analysed documents such as Tourism Development strategy offer only generalised development solutions. In order to encourage the inclusion of culture and tradition in the modern management of Požega-Slavonia County, and thus stimulate the development of this area, it is important to approach this problem in a complex and targeted manner. It is precisely the cross-cultural management which provides a good basis for further research into this problem.

\section{References}

[1] Anić, V. and Goldstein, I. (2007). Rječnikstranih riječi, Novi liber, ISBN 978-953-6045- 52-5, Zagreb [2] Belak, V. (2014). Menadžment u teoriji i praksi, Belak excellens d.0.0., ISBN 978-953-55423-4-6, Zagreb

[3] Bolfek, B. et al (2012). Polazišta za brendiranje Slavonije kao turističke destinacije, Ekonomski vjesnik: Review of Contemporary Enterpreneuship, Business, and Economic Issues, Vol. XXV., N No. 2, [363-374]

[4] Cifrić, I. (2014). Očuvanje baštine u kontekstu Europske unije, Adris: zbornik radova Zavoda za znanstveni i umjetnički rad Hrvatske akademije i umjetnosti u Splitu, №. 20, (9-19]

[5] Demonja, D. and Baćac, R. [2012). Baština i tradicija u oblikovanju turističke ponude u ruralnom prostoru Hrvatske, Podravina: časopis za multidisciplinarna istraživanja, Vol. 11, №. 21, (205218)

[6] Drucker, P. [2005]. Najvažnije o menadžmentu, M.E.P. Consult, ISBN 953-6807-24-6, Zagreb

[7] https://razvoj.gov.hr/o-ministarstvu/ regionalni-razvoj/indeks-razvijenosti/112, Access: [20-10-2018)

[8] Jelinčić, D. A. (2006). Turizam vs identitet, globalizacija i tradiciija, Etnološka istraživanja, №. $11,(161-183)$

[9] Kesar, 0. and Ferjanić, D. (2010). Ključni aspekti uspjeha u upravljanju razvojem enofilskog turizma u uvjetima svjetske gospodarske krize - slučaj Hrvatske, Acta turistica, Vol. 22, No. 1, (99-131] [10] Sikavica, P. and Bahtijarević-Šiber, F [2004). Teorija menadžmenta i veliko empirijsko istraživanje u Hrvatskoj, Masmedia, ISBN 953-157455-3, Zagreb 
[11] Strategija razvoja turizma Republike Hrvatske

do 2020. godine, Available on:

www.mint.hr/User/Docs/mages/Strategija-

turizam-2020-editfinal.pdf, Access: (23-10-2018)

[12] Vrtiprah, V. (2006). Kulturni resursi kao činitelj turističke ponude u 21. stolječu, Ekonomska misao i praksa, No. 2, (279-296)

[13] www.geert-hofstede.com, Access: (18-10-2018) [14] www. mint.hr, Access: (20-10-2018) [15] www. muzejuloncu. com, Access: [21-10-2018]

[16] www.tzzps.hr, Access: (19-10-2018]

[17] Žaper, A. (2004). Kullinarstvo - dio kulture življenja i duhovne baštine u hrvatskoj turističkoj ponudi, Naše more: znanstveno-stručni časopis za more i pomorstvo, Vol. 51, No. 5-6, [227-238]

[18] Županijska razvojna strategija Požzeškoslavonske županije 2016-2020., Available on: www.panora.hr, Access: (15-11-2018) 